\title{
"Believing the impossible"
}

\section{Imagining Science: Art, Science, and Social Change}

Sean Caulfield and Timothy Caulfield, editors

The University of Alberta Press; 2008.

105 pp $\$ 34.95$

"There is no use trying," said Alice, "one can't believe impossible things." "I dare say you haven't had much practice," said the Queen. "When I was your age ... sometimes I've believed as many as six impossible things before breakfast." - Alice in Wonderland, Lewis Carroll.

$\mathrm{S}$ o begins "Believing the Impossible," one of the many provocative essays in Imagining Science, an innovative collaboration among scientists, artists, bioethicists and others that investigates numerous contentious bioethical issues, such as stem cell research, genetic testing, patenting of genes and genetic selection of offspring.

This handsome publication is part of a project by brothers at the University of Alberta, Edmonton: Prof. Timothy Caulfield, Canada research chair in health law and policy and Sean Caulfield, a Canada research chair and professor of printmaking in the Department of Art and Design. In his introductory essay, Timothy Caulfield touches on the controversial social, ethical, legal and religious issues

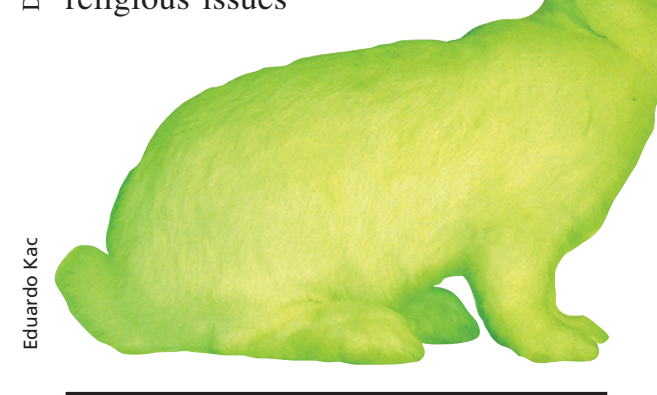

Eduardo Kac, Alba, the fluorescent bunny (2000).

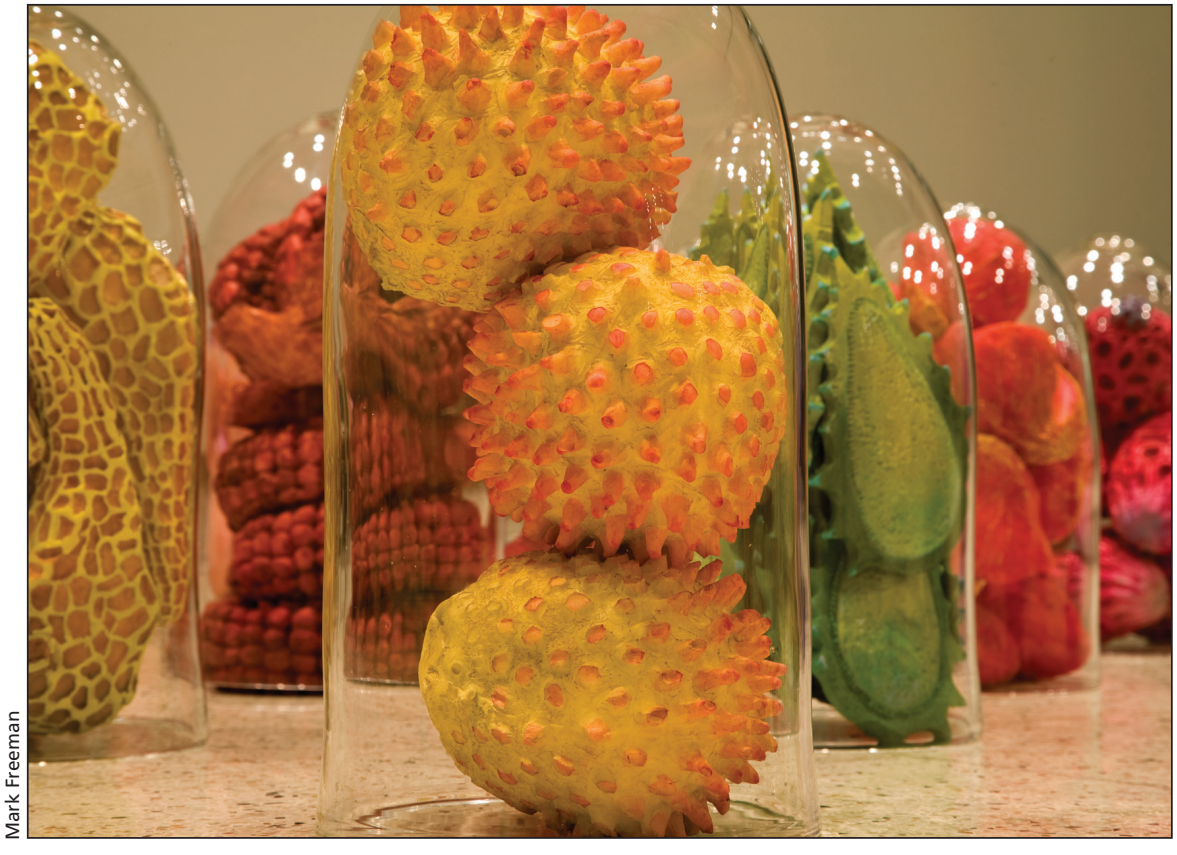

Lyndal Osborne, ob ovo (2008). Mixed media installation, glass, foam and paint. $6 \times 3 \mathrm{~m}$ (detail of a work in progress).

gripping the field of biotechnology and opines that artists are an important voice among the various commentators. Indeed, some artists play the role of provocateur, presenting works inspired by the imagined (or unimaginable) possibilities of biotechnology and some of these works bring the public face-to-face with challenging and troublesome issues in a

direct visceral way. The book features the work of 10 artists, along with 18 essays and a poem, all of which aim to shed new light from differing perspectives on biotechnology and the interplay between art and science.

Just as the title of the book is thought provoking, so too are some of the essays. "Believing the Impossible" advocates embracing uncertainty and the mysterious in thinking about biotechnology. Dr. Gail Geller, of Johns Hopkins University, Baltimore, Maryland, states "Every major ad- vance in scientific thinking - socalled scientific revolutions - has resulted because someone dared to believe the impossible." It's an inspiring thought!

"Half Human, Half Beast," by Cynthia B. Cohen, who served as a member of the Canadian Stem Cell Oversight Committee, tackles the notion of chimeras, a recurring theme in the book. She writes "Stem cell scientists now tell us that it is essential to develop human-nonhuman chimeras - living beings composed of both human and nonhuman cells - in order to pursue stem cell research." The potential medical benefits of this work are offset by the fear of creating animals that may think or act like humans. The diverse reactions of governments to stem cell research reflects the philosophical and scientific complexity of this emerging field. As Cohen points out, some countries, such as Canada, "prohibit funding research 

stem cells into ... embryos or fetuses." In contrast, the UK advocates that a regulatory body should control stem cell research licences on a case-by-case basis.

To many people, the possibility of more extreme human-nonhuman chimeras is troubling. Artists have advanced this discourse by creating art pieces that provoke the viewer into considering the potential and risks of transgenics. As biology becomes a more malleable discipline, some artists are starting to use the tools of science to make biological art. A case in point is Eduardo Kac's controversial GFP bunny: Alba, the genetically modified green fluorescent rabbit. Alba was created on Kac's request in 2000, by a lab in France that injected a synthetic mutation of the original wild-type green fluorescent gene found in the jellyfish Aequorea Victoria, into the rabbit embryo. Kac argues that GFP bunny is a transgenic artwork and not a breeding project. Worldwide reaction to the creation ranged from fascination to outrage.

Another contributor, Adam Zaretsky, presents photographic images from his "Transgenic Pheasant Embryology Art and Science Lab." One image, "Heritable Palette," shows an array of pheasant embryos in increasing stages involving the insertion of ... embryonic

of development laid out on an artist's palette, as though ready to be used to create some living artwork.

The beautiful cover of Imaging Science is from a series in the book by artist Christine Davis, who has projected colour slides onto the wings of a morpho butterfly. The images are indisputably beautiful, but one wonders how this work contributes to the role of artist as provocateur. Timothy Caulfield states that the book's purpose is to present "pieces that were provocative, engaging, and that would encourage readers to consider the social issues associated with biotechnology in a new light," but some of the artwork contributes little to that objective. The selection of the art work, apart from that of Kac, Zaretsky and Lyndal Osborne, seems timid, sometimes obscure, although certainly some are thoughtful and finely rendered, such as the mixed media pieces by Sean Caulfield. Missing here is work that is more directly

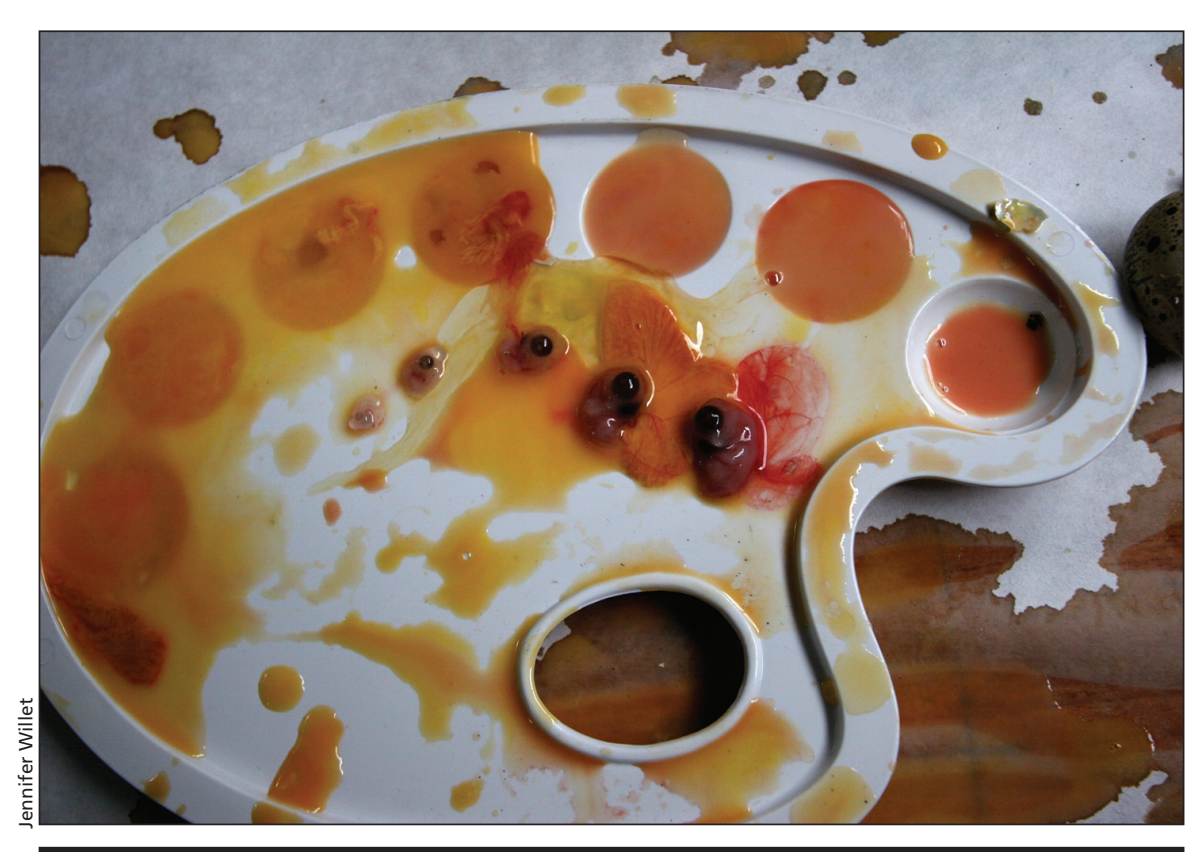

Adam Zaretsky, "Heritable Palette" (2007). Ink jet print. $1.22 \times 1.82 \mathrm{~m}$. Transgenic Pheas-

ant Embryological Arts Lab, Leiden University Honours Program. Courtesy of VivoArt.

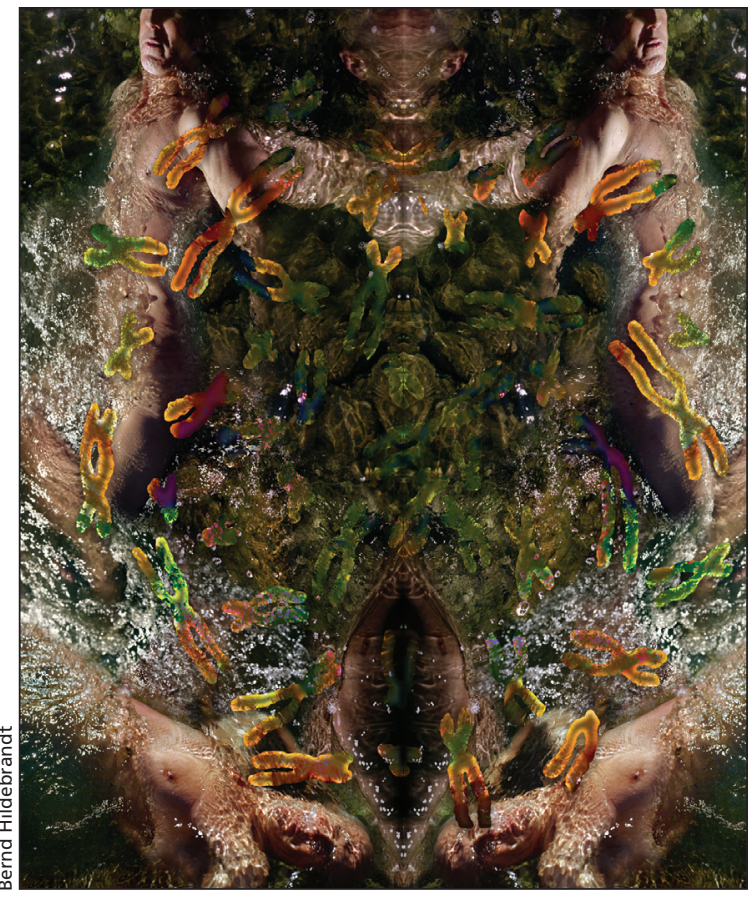

Liz Ingram and Bernd Hildebrandt, Perplexed Realities (2008). Dye sublimation digital output on fabric, Plexiglas rods, vinyl type. $410 \times 266 \times 10 \mathrm{~cm}$. Courtesy of the artists. This is a computer rendering of a proposed on-site installation at the Art Gallery of Alberta, Edmonton, Alta. provocative, like that of Australian artist, Patricia Piccinini. One of her sculptural works, The Young Family, depicts a female figure that appears to be equal parts dog and human, suckling 3 offspring, while a fourth plays nearby, looking very cute, freakish, but somehow strangely natural.

This is a small criticism however, of a book that offers so much stimulating material. It should appeal to a broad audience of general public as well as professionals (including artists) involved in the biosciences. When you look through it, have Google near at hand since the contributors provide or spin off many juicy references. While reading this book, I spent as much time eagerly surfing as I did looking at the actual pages. Probably a sure sign of a good read in our age.

\section{Stuart Kinmond BArch}

Visual artist

Ottawa, Ont.

Kinmond started university in engineering physics, graduated in architecture and is now a full-time visual artist. 